\title{
$1 \quad$ Fighting for a Global Community in a Post-COVID World
}

\author{
Haruko SATOH
}

\begin{abstract}
This chapter argues that the COVID-19 pandemic has exposed the weaknesses of the UN system. This system becomes ineffective when the United States fails to lead during global health crises. At the regional level, the COVID-19 responses in Asian countries have shown that China cannot garner enough trust to replace the US as a leading power to maintain regional order. China was not transparent enough in handling the new virus at the start of 2020. Besides, Beijing's intimidation tactics towards, among others, Hong Kong, Taiwan, and Australia, continued unabated during the first year of the COVID-19 pandemic. These incidents highlight the importance of the US presence in the region. The chapter concludes that restoring trust in the US as the beacon of democracy and openness is crucial.
\end{abstract}

Keywords: international community, United Nations (UN), public health, US-China rivalry, COVID-19, international order

The COVID-19 pandemic has been a profound reminder that international cooperation in the United Nations (UN) system cannot be taken for granted, even in the face of a global health crisis where millions of lives may be at risk. The World Health Organization (WHO) saw its 'directing and coordinating authority' to lead the world out of the pandemic hampered from the outset as it became embroiled in a blame game between the United States and China. The US not only forfeited its leadership role but also became part of the problem as then president Donald Trump refused to publicly aknowledge the gravity of the new virus (Woodward 2020; Forgey and Choi 2020).

Van der Veere, Anoma P., Florian Schneider, and Catherine Yuk-ping Lo (eds), Public Health in Asia during the COVID-19 Pandemic: Global Health Governance, Migrant Labour, and International Health Crises. Amsterdam, Amsterdam University Press 2022 DOI: 10.5117/9789463720977_CHO1 
China tried to compensate for its initial missteps in handling the outbreak by engaging in 'mask and test kits diplomacy' (and later 'vaccine diplomacy') toward affected countries. However, these Chinese diplomatic actions met with a mixed reception, particularly in Asia where many are concerned about China's expansionist intent (Chellaney 2020). While the WHO was vilified for failing to rise above this rivalry between major powers, the context in which this occurred is equally, if not more, problematic. The growing US-China rivalry has far-reaching implications for restoring global trust in the UN system of international cooperation.

This chapter takes a broader view of the COVID-19 pandemic. It sees this as a crisis to the system of global governance in relation to the future of the liberal international order, with a focus on the the Asia-Pacific region.

The responses of Asian states to COVID-19 have varied, ranging from highly organized approaches to muddling through. Asian states were arguably more concerned by the abrupt changes to economic conditions, such as border closures and restricted mobility, than by the debates that divided societies in Europe and North America over effective measures for controlling the spread, such as wearing face masks and lockdowns. ${ }^{1}$

Most Asian states had experienced pandemics before, which meant they were better prepared to manage the crisis in terms of institutional capacities, having already developed aspects of the healthcare system needed to respond to pandemics and information technology that allowed them to carry out 'track and trace' of patients (Fitzgerald and Wong 2020; Pardo et al. 2020). Moreover, for most governments in Asia, hard lockdowns tended to be a reluctantly pursued 'last resort' option. This debunks the notion that Asian governments tend to be more authoritarian and that Asian societies are more compliant and group-oriented (Nikkei Asia 2020).

However, it should be noted that Asia is seeing arguably more profound political changes than other regions of the world. The region is also beset by uncertainty over a US-China rivalry, which is affecting the regional order. In this way, Asia could be seen as a microcosm of what could happen globally with regards to America's diminished standing in the world and its ability to maintain the liberal international order in the face of China's apparent revisionist intentions. By focusing on the Asia-Pacific region, this chapter argues that US actions (or inactions) have been most consequential during

1 Mask-wearing was not a hugely contested issue as East Asians are accustomed to wearing face masks during the flu and hay fever seasons, and also to protect against harmful airborne particulates (PM 2.5) produced by industrial activities and heavy urban traffic. 
this pandemic in undermining the global community's confidence in the UN system as represented by the WHO.

\section{Global Community Matters}

It has been three decades since the Berlin Wall collapsed in 1989, and since the end of the ideological conflict between the 'free world of the West' and the communist bloc, respectively led by the two superpowers, the US and the Soviet Union. In 1991, the first Gulf War then brought together the former enemies to agree at the UN Security Council that Iraq needed to be driven out of Kuwait. This moment sparked the hope that the UN might finally be on the track to function as originally intended, as a world government and a 'peace factory' (Solana 2020).

Although declarations made at the time of a 'new world order' and the 'end of history' (Fukuyama 1989; 1992) were evidently premature, the UN neverthless gained renewed relevance at this time. It was called upon to take charge of a significant portion of problems and challenges of the post-Cold War world. One indicator of this growth in UN activities can be seen in rise in the number of UN Security Council resolutions that have been passed since 1990. Until then, there had been less than 700 resolutions (the resolution that sanctioned the use of force against Iraq was number 678 ). However, in the three decades since 1990 there have been nearly 2000 additional resolutions (UN 2021). Also, importantly, at this time the notion of the 'global' took hold of people's imagination and became part of the lexicon of diplomacy and international politics (Iriye 2002, 159).

The post-Cold War era was characterized by the emergence of a world of borderless, near-global connectivity. The globalization of capitalism brought an unprecedented level of economic development and growth to vast parts of the world. Rapid advances in information technology, especially the advent of the Internet, hastened the pace of this globalization. This in turn increased the level of interdependence between nations and economies at the level of everyday life, creating a realm where the role of states receded to the background. This also meant that the notion of security broadened in tandem with global social and economic transformation. An entirely new category of non-traditional security (NTS) issues, such as climate change, pollution, international terrorism, mass migration, and infectious diseases were identified as threats to international peace and security. In short, it was a world where 'my concern is your concern, too'. 
Yet, the UN system and the global community it represents are inherently fraught with political tension. The differences in the political systems and value systems of the UN member states, combined with the principle of upholding state sovereignty, make joint action difficult (Satoh 2021). Although the UN has a general charter that espouses certain 'universal values', it does not make state membership conditional based on shared values in the way the European Union (EU) does. The UN's paradoxical set-up of respecting the sovereignty of member states while at the same time asking for the transference of sovereign rights requires intense negotiations for consensus-building among member states. At worst, the UN system risks becoming a 'spoils system that puts too many people in important positions for reasons other than competence, lack of accountability, and hypocrisy' (Haass 2020). An example of this might be the way that countries that ignore human rights sit on a UN body meant to uphold them.

In this sense, the problems that the WHO initially encountered in handling the outbreak of COVID-19 were neither unforeseen nor new. First, China's track record for transparency and openness was questionable even before the pandemic (Stanway 2020; Perper 2020). Second, the WHO has no enforcement power and can only issue guidelines for the member states to voluntarily follow. Third, great power rivalry obstructing international cooperation in the UN system is, as explained above, endemic, if not the norm. Last, but not least, intensifying China-US rivalry over trade, geopolitical influence, and concerns about the fate of the rule-based, international order was already foreshadowing difficult times ahead for the UN and multilateralism in general (Satoh 2021).

\section{The Trump Problem}

What the global community did not foresee this time, however, was the extraordinarily uncooperative behaviour of the 'America First' president Donald Trump and his administration in handling the pandemic. After he took office in 2017, and through until his defeat in the 2020 presidential election, Trump wantonly undermined the liberal international order of alliances and international institutions of American design, showing a disdain for multilateralism. However, very few (if any) could have predicted that under Trump the US would become one of the countries worst hit by the pandemic, counting over 300,000 deaths by the end of 2020 . That 2020 was an election year did not help, as Trump appeared more concerned with winning a second term in the November elections than saving lives (Shear 2020). He knowingly ignored the science, tweeted misinformation, and 
turned (non-)mask wearing into a political statement. At the same time, he blamed others, including his chief public health advisor Anthony Fauci, the former president Barack Obama, and above all China and the WHO, for the consequences of the political and public health mayhem that his administration's inaction was causing (Forgey and Choi 2020; Woodward 2020).

China's missteps and the WHO's alleged complicity in downplaying the danger of the new virus rightfully drew international criticism. However, Trump made no attempt to salvage the WHO's reputation, even though the US was its largest donor. Instead, he chose to punish the WHO by first freezing funding and then withdrawing the US from the organization altogether. In this way, Trump essentially reduced the pandemic and the WHO to mere props to enhance his popularity as a MAGA (Make America Great Again) leader who is 'tough on China'.

Under Trump's successor, Joe Biden, the US has now rejoined the WHO, as well as the Paris climate accord which the US officially left in November 2020 (BBC 2020; Biden 2020). These are important steps for the US to recover lost international ground. However, the Trump administration had also chiselled away at America's democracy, which is arguably a deeper concern to the global community esconsed in the US-led liberal international order. For allies and many parts of the world that looked to the US as the beacon of democracy, faith in liberal values, such as in the freedom, human rights, and transparency undergirding this international order, was badly shaken (Kaufman 2017; Stokes 2018).

While the US has never been a natural multilateral player, the effectiveness of international organizations, such as the WHO, in providing global public goods has depended greatly on America's willingness and ability to do the same. That is why Trump's excessive unilateralism and attack on democracy are tantamount to a crisis in the entire international system.

\section{The Impact on the Asia-Pacific}

The Asia-Pacific region is the main arena where China is challenging the USled post-1945 order. This order is frequently described as a hub-and-spokes (San Francisco) system of bilateral alliances (with Japan, South Korea, Australia, the Philippines, and Thailand). The COVID-19 pandemic hit at the time when China was increasingly becoming assertive, while the US commitment to Asia-Pacific regional security was waning under the Trump presidency.

In recent years, the Asia-Pacific region had seen various examples of China's 'wolf warrior' diplomacy and muscle flexing, including the maritime 
territorial disputes in the South and East China Seas, Beijing's attempts to quash demonstrations in Hong Kong, increasing bullying of Taiwan (including its exclusion from the WHO; Chen and Cohen 2020), and the recent intimidation of Australia after it asked China to account for the origins of the coronavirus.

Yet, with Trump behaving more as a kindred spirit of the neo-authoritarians' (Wright 2018) than as a leader of democracies, China's challenge to the status quo was alarming not only to US allies in Europe, but also to democratic allies in Asia, such as Japan, South Korea, and Australia. These allies in Asia all have a higher stake in maintaining the ruled-based, international order in the region. In this regard, the COVID-19 pandemic's impact on the Asia-Pacific regional order offers insights into why restoring trust in the UN system is contingent upon how the US recovers from the international impact of Trumpism.

Regionalism in the sense of community development is a work-in-progress in the Asia-Pacific region. The region does not have a values-based, overarching organization like the EU or a security architecture like the North Atlantic Treaty Organization (NATO). There are democracies as well as communist or military-led authoritarian regimes. The principle of noninterference prevails across the region, such that many consider it as 'the most Westphalian region' (Howe 2020). While security has long relied on the hub-and-spokes system, the spoke states are not necessarily friendly toward each other, as seen in the case of Japan and South Korea. As the chief architect of the regional order, commitment from the US is therefore crucial to the system's cohesion and survival (Richey 2019).

On the other hand, there is another layer of the region's relations that has primarily been economically driven, where Northeast and Southeast Asia are highly economically interdependent and interwoven as a production network (Kimura and Obashi 2011). The Asia Pacific Economic Cooperation (APEC), a regional forum that was established in 1989, is representative of how the region often prioritises economic development and interdependence over issues such as democracy and human rights. Therein lies the paradox where China, Japan, and South Korea can be politically antagonistic toward each other, and yet still maintain closely knit economic ties with each other, and also with Southeast Asia.

In this complicated landscape, regional political dialogue and mechanisms for cooperation have evolved around the Association of Southeast Asian Nations (ASEAN). The institution's role has been indispensable in facilitating multilateral dialogues, such as the ASEAN Regional Forum (ARF), the various ASEAN plus formulas and the East Asia Summit that involve 
all stakeholders, including China, the US and Russia (see the contribution by Koga about ASEAN in this volume).

However, despite these regional forms of cooperation, there continues to be great importance attached to US presence - as a democracy and provider of public goods, such as safety of navigation - as the regional order evolves. Yet, during the Trump presidency the US failed on both fronts: as the beacon of democracy and the guarantor of stability for the region.

Trump's 'tough on China' agenda was welcomed in some security circles in Japan or Australia. However, this agenda did not translate into a stronger hub-and-spokes system or enhanced multilateral dialogue. Instead, the alliance politics and multilateralism in Asia faced difficulties with Trump's transactional style of 'America First' diplomacy, in a similar way to NATO. That said, we need to note here that the attempts by Trump's predecessors, George W. Bush and Barack Obama, to engage with China also had their strengths and weaknesses. These two former presidents presided over the US' China policy during nearly two decades in which China was rapidly transforming. They were responding to a rising country whose economic importance became undisputed. However, the ramifications of a rising China for regional security order were not then clear, nor did they occupy the same central position in in US policy toward Asia as they have since.

Whatever one might think of these two former presidents' policies toward China, however, neither of them allowed the hub-and-spokes system to fragment by ignoring multilateral frameworks in the way that Trump did. For example, a fallout between Japan and South Korea, the two most important US security allies in Asia, took place in the 'shadow' of Trump's theatrical, but ineffective, dealings with the North Korean dictator Kim Jong-un. The Japan-South Korea relationship is now at its lowest point since the normalization of relations between the two countries in 1965 (Satoh 2020). During his time as president, Trump only attended two APEC meetings (2017 in Da Nang, Vietnam and 2020 in Kuala Lumpur, Malaysia, the latter held virtually), and he attended none of the East Asian Summits. His withdrawal of the US from the Trans-Pacific Partnership in his first year in office was an ominous sign for a region where managing economic relations is an integral part of regional stability.

\section{The Trust Deficit}

As has been mentioned earlier in this chapter, the COVID-19 pandemic hit at a time of growing regional uncertainty about the extent to which the US 
would intervene in China's attempts to challenge established norms. At a global level, trust in the US became a rare commodity as its ability to lead diminished. The regional response to the pandemic revealed a complex interplay of 'untrusting' relations between the US, China, and the regional states. This occurred as part of an on-going order transition from one based on the hub-and-spokes system to one where China may become dominant. The question boiled down to trust, and who to trust, with trust remaining in short supply.

People in different parts of Asia, such as in Vietnam, Singapore, and Hong Kong, had not forgotten China's mishandling of the 2002-3 Severe Acute Respiratory Syndrome (SARS) pandemic. At that time, China reportedly hid the outbreak in Guangdong from the WHO for several months (Martin 2020; Perper 2020). Therefore, when COVID-19 outbreaks occurred, China's apparent attempts to once again obfuscate the origins of a new coronavirus, including its unwillingness to allow WHO inspections (Euronews 2021), deepened the region's inherent mistrust towards it. After this, it appeared that no amount of 'mask diplomacy' was going to win China trust from regional states (Kausikan 2020).

However, the humanitarian and political disasters caused by the White House's misinformation about the virus were arguably a deeper concern to people in Asia, and the region's faith in the US took a nose-dive. If China's problem was suppressing inconvenient facts, America's problem was that it had no use for truths, let alone facts.

The attitudes of ASEAN states toward China and the US are, in this case, illuminating as they are informed by their past colonial experiences and the Cold War bipolar system. These experiences have left ASEAN states with a strong desire to maintain autonomy and to avoid entanglement in great power rivalry. The current regional organization was formed, after all, during the ideological divide between the US and the Soviet Union. ASEAN countries remain wary of taking sides, nowadays between the US and China. Maintaining manoeuverability by hedging is their key strategy. They are cautious toward both China and the US, although the sense of threat and suspicion toward China is traditionally greater. A Singaporean think tank's survey (mainly of government officials, academics and researchers in think tanks, and businessmen) proves these points vividly: while a majority $(52.2 \%)$ acknowledge China to be the greatest political and strategic power in Southeast Asia, $53.5 \%$ also see it as a threat (corresponding percentages for the US are $28.7 \%$ and $21.8 \%$, respectively). Regarding what choices ASEAN should make based on US-China rivalry, $48 \%$ chose to 'enhance ASEAN resilience and unity', while $31.1 \%$ chose 'not siding with China or 
US'. This may reflect some wishful thinking, as well as ASEAN's penchant for hedging (ISEAS 2020).

Indeed, ASEAN's preference for avoiding entanglements in great power rivalry makes multilateralism and rule-based international order important. This preference also makes other multilateral players, such as Japan and the EU, attractive in the eyes of ASEAN states. While China and the US, the two great powers that can act unilaterally, are regarded with caution, these other multilateral players are viewed more favourably. In the same survey, over $60 \%$ expressed little or no confidence in China to 'do the right thing to contribute to global peace, security, prosperity and governance'. For the US, this percentage is just under $50 \%$. By comparison, Japan and the EU respectively receive a $61.2 \%$ and $38.7 \%$ confidence rating. Japan is considered a threat by only $5.0 \%$ of respondents, while the $\mathrm{EU}$ is considered a threat by just 3.5\%.

At the same time, only $10.5 \%$ of respondents saw China as a 'responsible stakeholder that respects and champions international law'. This is compared to $15.4 \%$ for the US, $51 \%$ for Japan, and $68 \%$ for the EU (ISEAS 2020, 16-18). That ASEAN does not trust either China or the US to 'do the right thing' should be food for thought for the Biden administration as it plans for the US to make its comeback as a global leader.

However, future US engagement in Asia needs to be more mindful of the complex structure of the political economy in the region. As mentioned earlier, in Asia taking sides or 'decoupling' from China is not an option. This applies to the two main hub-and-spokes allies, Japan and South Korea. We might also note that democracy as a preferred political system has come to matter more than before in Asia, especially at the grassroots level. This is in reaction to what has been described as China's 'salami-slicing strategy'. It has been suggested that China uses this strategy to slowly undermine the integrity of countries and organizations. To this end, it has been argued that China uses a combination of diplomatic and economic tools (such as the creation of debt traps), soft and hard power, and technology to make inroads into countries and organizations (Chellaney 2013).

China's encroachment and the COVID-19 pandemic have highlighted the importance of the political side of the liberal international order. Issues of transparency and accountability have become more important as states have sought to ensure accurate information and trust-based international cooperation to combat COVID-19. Most Asian states, including China, had taken advantage of the liberal economic order for their development. Some of these states have been ambivalent, if not hostile, toward embracing democracy because they saw it as a Western imposition. However, this situation may be changing. The presence of the US as an 'Asian power' in 
this context would be important. However, this makes the damage done to US credibility by the Trump presidency all the more of a grave concern, both to the region as well as to states around the world.

\section{Coda}

It might be worth noting that the pandemic has not necessarily strengthened China's position in the region, although it has emerged as the only country to register economic growth in 2020. If anything, it has demonstrated that China is no more qualified to be a global leader than the US was under Trump. This is largely because China's expansionist actions continued unabated throughout the year when regional states and regions were all struggling to handle the COVID-19 outbreak. Its actions in Hong Kong were arguably most noticeable, with the imposition of its new national security law in June 2020 (Maizland and Albert 2020). That said, there is growing recognition that the question of how democratic governance can take firmer root in Asian countries is tied to the future form and shape of regional order.

Recognition of the need to protect or fight for democracy as a political system, and to keep the liberal international order, has only a limited place in the political evolution of the Indo-Pacific. The goal for many Asian states is not necessarily to become liberal democracies in the model of Europe and North America. Rather, Asia's path to democracy is being shaped out of a social and political struggle that involves pushing back postcolonial legacies, the strong role of the military, a resistance to the imposition of 'universal' values, and a guarded stance against China.

\section{Bibliography}

BBC. 2020. 'Coronavirus: Biden Vows to Reverse Trump WHO Withdrawal.' 8 July. Accessed 10 December 2020. https://www.bbc.com/news/ world-us-canada-53332354.

Biden, Jr, Joseph R. 2020. 'Why America Must Lead Again: Rescuing U.S. Foreign Policy After Trump.' Foreign Affairs, March/April. Accessed 2 November 2020. https://www.foreignaffairs.com/articles/united-states/2020-01-23/ why-america-must-lead-again.

Chellaney, Brahma. 2013. 'China's Salami-slice Strategy.' The Japan Times, 25 July. Accessed 10 October 2020. https://www.japantimes.co.jp/opinion/2013/07/25/ commentary/world-commentary/chinas-salami-slice-strategy/\#.Xu84jpozbIU 
Chellaney, Brahma. 2020. 'China's Expansionism Enters Dangerous Phase.' The Japan Times, 25 August. Accessed 10 November 2020. https://www. japantimes.co.jp/opinion/2020/08/25/commentary/world-commentary/ china-expansionism/

Euronews. 2021. 'WHO Chief Criticizes China after Beijing Fails to Give Clearance for COVID-19 Inspection Mission.' 5 January. Accessed 10 January 2021. https:// www.euronews.com/2021/01/05/who-chief-criticises-china-after-beijing-failsto-give-clearance-for-covid-19-inspection-m.

Fitzgerald, Dominic A., and Gary W.K. Wong. 2020. 'COVID-19: A Tale of Two Pandemics across the Asia Pacific Region.' Pediatric Respiratory Reviews vol. 35: 75-10. Accessed 31 October 2020. https://doi.org/10.1016/j.prrv.2020.06.018.

Forgey, Quint, and Matthew Choi. 2020. "This is Deadly Stuff”: Tapes Show Trump Acknowledging Virus Threat in February.' Politico, 9 September. Accessed 10 November 2020. https://www.politico.com/news/2020/og/og/ trump-coronavirus-deadly-downplayed-risk-410796.

Fukuyama, Francis. 1989. 'The End of History?' The National Interest 16: 3-18.

- 1992. The End of History and the Last Man. New York: Free Press.

Haass, Richard. 2020. 'The UN's Unhappy Birthday.' Project Syndicate, 10 September. Accessed 10 October 2020. https://www.project-syndicate.org/commentary/ united-nations-75th-anniversary-little-to-celebrate-by-richard-haass-2020-09. Howe, Brendan. 2020. 'Comprehensive Security and Sustainable Peacebuilding in East Asia: Reflections on a Post-COVID-19 Operating Environment.' The Korean Journal of Security Affairs vol. 25, no. 1 (July): 5-33.

Iriye, Akita. 2002. Global Community: The Role of International Organizations in the Making of the Contemporary World. Berkeley: University of California Press. Kaufman, Joyce P. (2017). 'The US Perspective on NATO under Trump: Lessons of The Past and Prospects for the Future.' International Affairs vol. 93, no. 2: 251-266. https://doi.org/10.1093/ia/iixoog.

Kausikan, Bilahari. 2020. 'No, China Will Not Get Away with Rewriting History.' Nikkei Asia, 30 March. Accessed 30 March 2020. https:/asia.nikkei.com/Opinion/ No-China-will-not-get-away-with-rewriting-history.

Kimura, Fukunari, and Ayako Obashi. 2011. 'Production Networks in East Asia: What We Know So Far.' ADBI Working Paper 320. Asian Development Bank Institute. November. Accessed 1o October 2020. http://hdl.handle.net/10419/53625.

Maizland, Lindsay, and Eleanor Albert. 2020. 'Hong Kong's Freedoms: What China Promised and How It's Cracking Down.' Backgrounder, 17 February. Council on Foreign Relations. Accessed 6 November 2020. https://www.cfr.org/ backgrounder/hong-kong-freedoms-democracy-protests-china-crackdown.

Nikkei Asia. 2020. 'From Light Touch to Total Lockdown: How Asia Is Fighting Coronavirus.' 20 March. Accessed 10 October 2020. https://asia.nikkei.com/ 
Spotlight/Coronavirus/From-light-touch-to-total-lockdown-How-Asia-isfighting-coronavirus.

Pardo, Pacheco Ramon, Mauricio Avendano Pabon, Xuechen Chen, Bo-jiun Jing, Jeong-ho Lee, Joshua Ting, Takuya Matsuda, and Kaho Yu. 2020. Preventing the Next Pandemic: Lessons from East Asia, Faculty of Social Science \& Public Policy, Kings College London, May. https://www.kcl.ac.uk/eis/assets/ kdefsresearchreport2020-a4-proof2-singlepage.pdf.

Perper, Rosie. 2020. 'The Last Time China Was Hit by a Deadly Illness Like the Wuhan Coronavirus, It Covered It up and 774 People Died. There Are Fears It Could Happen Again.' Insider, 21 January. Accessed 21 January 2020. https://www. businessinsider.com/china-wuhan-virus-sars-similarity-china-coverup-2020-1.

Satoh, Haruko. 2020. 'Japan and Korea: A Fragile Relationship.' East Asian Policy vol.12, no. 3 (July/September): 92-103. https://doi.org/10.1142/S1793930520000252.

- 2021. 'Great Power Relations and Threats to the Liberal International Order.' Hiroshima Peace Research Journal vol. 8: 53-70.

Shear, Michael. 2020. 'Biden Implores Trump to Confront a Surging Pandemic.' The New York Times, 13 November. Accessed 10 January 2021. https://www.nytimes. com/2020/11/13/us/politics/biden-trump-coronavirus-transition.html.

Solana, Javier. 2020. 'Reopening the Peace Factory.' Project Syndicate, 21 September. Accessed 31 October 2020. https://www.project-syndicate.org/commentary/united-nations-anniversary-liberal-international-order-by-javier-solana-2020-o9.

Stanway, David. 2020. 'The Shadow of SARS: China Learned the Hard Way How to Handle an Epidemic.' Reuters, 22 January. Accessed 10 October 2020. https:// www.reuters.com/article/us-china-health-sars-idUSKBN1ZL12B.

Stokes, Doug. 2018. 'Trump, American Hegemony and the Future of the Liberal International Order.' International Affairs vol. 94, no. 1(January): 133-150. https:// doi.org/10.1093/ia/iix238.

United Nations. 2021. As of 29January 2021, the United Nations Security Council Resolution Count Is at 2561. https://www.un.org/securitycouncil/content/resolutions.

Woodward, Bob. 2020. 'Mr Trump Knew It Was Deadly and Airborne.' The New York Times, 9 September. Accessed 31 October 2020. https://www.nytimes. com/2020/og/og/opinion/trump-bob-woodward-coronavirus.html.

Wright, Thomas. 2018. 'The Return to Great-Power Rivalry Was Inevitable.' The Atlantic, 12 September. Accessed 10 October 2020. https://www.theatlantic.com/ international/archive/2018/og/liberal-international-order-free-world-trumpauthoritarianism $/ 569881 /$.

Yusof Ishak Institute of Southeast Asian Studies. 2020. The State of Southeast Asia: 2020 Survey Report, 16 January. ASEAN Studies Centre. Accessed 15 October 2020. https://www.iseas.edu.sg/wp-content/uploads/pdfs/TheStateofSEASurveyReport_2020.pdf. 


\section{About the Author}

Haruko SATOH is co-director of the IAFOR Research Centre at the Osaka School of International Public Policy, Osaka University, a member of IAFOR's Academic Governing Board, and Chair of the Politics, Law \& International Relations section of the International Academic Advisory Board. She is a member of the International Advisory Board at the Leiden Asia Centre at Leiden University. She is a Specially Appointed Professor at the Osaka School of International Public Policy (OSIPP), where she teaches about topics including Japan's relations with Asia and identity in international relations. She was previously part of the MEXT Reinventing Japan project on 'Peace and Human Security in Asia (PAHSA)' with six Southeast Asian and four Japanese universities. 
